\title{
ArcheoSciences
}

Revue d'archéométrie

\section{AURUM: Archaeometry and authenticity of gold}

AURUM : Archéométrie et authenticité de l'or

\section{Maria Filomena Guerra and Thilo Rehren}

\section{(2) OpenEdition}

\section{Journals}

Electronic version

URL: https://journals.openedition.org/archeosciences/1894

DOI: 10.4000/archeosciences.1894

ISBN: 978-2-7535-1598-7

ISSN: 2104-3728

Publisher

Presses universitaires de Rennes

Printed version

Date of publication: 31 December 2009

Number of pages: $13-18$

ISBN: 978-2-7535-1181-1

ISSN: $1960-1360$

\section{Electronic reference}

Maria Filomena Guerra and Thilo Rehren, "AURUM: Archaeometry and authenticity of gold",

ArcheoSciences [Online], 33 | 2009, Online since 09 December 2012, connection on 01 February 2022

URL: http://journals.openedition.org/archeosciences/1894 ; DOI: https://doi.org/10.4000/

archeosciences. 1894

This text was automatically generated on 1 February 2022

Article L.111-1 du Code de la propriété intellectuelle. 


\title{
AURUM: Archaeometry and authenticity of gold
}

\author{
AURUM : Archéométrie et authenticité de l'or
}

Maria Filomena Guerra and Thilo Rehren

1 The appeal of gold is near-universal, and throughout history almost all metal-using cultures have put gold at the top of their list of desirables. Even today, with other metals being more expensive and more versatile to use, gold holds a particular fascination for most of us. The unique aesthetic qualities of gold and its alloys - their subtle range of colours - and its smooth untarnished surface quality even after years and, as we see with the many objects studied in this volume of ArcheoSciences, millennia of use - like a representation of eternal youth - are certainly the reasons of that attraction.

2 The workshop from which the papers presented in this volume of ArcheoSciences originate was entitled AURUM: authentication and analysis of goldwork. It was organised under the auspices of the EU-DG Research funded project AUTHENTICO (Authentication methodologies for metal artefacts based on material composition and manufacturing techniques) n. 044480 under the $6^{\text {th }}$ Framework Programme. The main aim of this project, including ten partners from eight different countries and co-ordinated by Maria Luisa Vitobello, director of the European Jewellery Technology Network, was to develop tools and expertise for law enforcement agencies to combat illicit trade in antiquities and to fight fraud and forgeries. Access to the results of AUTHENTICO is necessarily restricted; AURUM acts as the public face of AUTHENTICO, within the academic ethos of open discussion, free flow of information and sharing knowledge. During the three days of the work-shop in May 2009, more than 115 participants from over 28 countries (Austria, Belgium, Brazil, Bulgaria, Canada, Colombia, Cyprus, Czech Republic, Egypt, France, Greece, Germany, Hungary, Iran, Ireland, Italy, Malta, Mexico, The Nedherlands, Portugal, Romania, Russia, Spain, Switzerland, Tajikistan, Tunisia, United Kingdom, and the United States of America) participated in wide-ranging discussions, spanning the entire spectrum of aspects indicated above (Fig. 1). Many more wanted to come; but the room available simply did not allow more people to attend. This 
overwhelming interest, not only from scholars but also the wider public, represented by government officials, a member of the European Parliament, representatives of two European Law Enforcement Agencies - the Command Office Carabinieri, Department for the Protection of Cultural Heritage in Rome, and the Central office for the Fight against Traffic in Cultural Goods of the French Criminal Investigation Department - and the press, encouraged us to prepare the presentations for swift publication.

3 This collection of papers offers but a glimpse of some of the main themes played out by gold, both in the past, but also in today's world. Even though wonderful gold objects can be easily produced by simple casting and hammering, such as the Scythian ornaments studied by Armbruster and the finds from the royal tombs of Sipán analysed by Cesareo et al., the most delicate objects have been made from gold, by the most skilful artisans of their times, multiplying the worth of the metal with the value of their craft. The elbow fibula from the Phoenician tomb of Kition in Cyprus, studied by Vitobello and Flourentzos and Guerra and Rehren, the Celtic 'Tara' brooch described by Whitfield, the belt buckle found in a princely grave from Apahida in Romania dissected by Oanta-Marghitu, the adult's necklace of the Qurneh burial near Luxor studied by Tate et al., and the bimetallic discs from Monte Alban, Oaxaca presented by PeñuelasGuerrero et al. are just a few examples of the artisans' skills at different periods treated in this volume.

4 The functions of the objects fabricated with gold were manifold: they include everyday jewellery from antiquity (such as in Ras Shamra, as reported by Prévalet, and from the Phoenicians, see Ferro et al.) to modern times (as in the $19^{\text {th }}$ century, described by Donati), funerary objects (studied by Ilieva and Penkova and Tonkova and Penkova), offerings and worship items (illustrated in the paper by Brito and Chaire), coins (analysed by Duttine et al. and Parreira et al.), insignia of power, and even intermediate shapes such as ingots for transporting the precious metal and for use in trade. By using different gold alloys or/and by adding gems, glass, enamel, and other more or less precious materials to gold objects, polychromy was achieved by the artisans. The Egyptians (as shown by Troalen et al.), the Minoans and the Mycenaeans (as illustrated in the paper by Adrimi et al.) used that technique already in the Bronze Age. Other techniques, such as gold inlay (described by Shemakhanskaya et al.), gilding (an overview of this technique in Germany is given by Aufderhaar), plating (examples are given by Saprykina et al. and by Eniosova), and patination (Pacini shows how to produce ancient patinas) can be used to make entirely or partially golden objects. The production of those objects can change over time, responding to religious, political, or other needs, or yet to the taste and style of each period, as exemplified in the 'archaeological style' of objects produced in the $19^{\text {th }}$ century by renowned goldsmiths such as Castellani; the study of the jewellery from a royal casket produced in Castellani's workshop is presented by Oliveira et al.

But gold has other resonances, too. Gold is power. Whoever controls the gold sources controls the economy. Many myths, like those of Jason and the Golden Fleece, of the El Dorado, and of King Midas, are linked to the quest for gold and its recovery from alluvial deposits, the first to be exploited. However, such mythic sources of gold are as difficult to locate in the present as they were in the past (see Hauptmann et al. and Adrimi et al. for the myth of Jason and the Golden Fleece), which is true also for other sources used more recently (as exposed by Ortiz Díaz for Mesoamerica, by Duttine et al. for South America and by Constantinescu et al. for Eastern Europe). Throughout 
history, battles and wars, migrations and shifts in population were triggered by the search for gold sources or the desire to control them. The gold rushes in, for example, Alaska, Klondike, California, Witwatersrand, and Serra Pelada are recent examples of this. In their time, the Romans knew it when they went to Spain; the Arab rulers applied it in their quest for North Africa in the early Islamic period, the Spanish and the Portuguese when they went to South America, and the British Empire in its more recent occupation of South Africa. Gold has been at the heart of money for millennia. Even after putting an end to the traditional gold standard in their meeting in Bretton Woods in 1944 and the subsequent unilateral decision by the US Government to break the fixed link between the dollar and gold metal in 1971, governments around the world still stockpile vast quantities of the metal and exert political and economic pressure with their tons of gold.

of course, in cultural heritage contexts the material value of gold is further exacerbated by the exclusive appeal of pieces of art and the very limited and nonrenewable nature of the resource. This rarity in itself drives desire. Archaeological gold objects combine in them all these multiple connotations, further enhancing each other in complex ways. As a result, archaeological gold objects attract particular attention; some of it good, some less so. As early as 1237, King Henry III of England issued a Royal Charter which required Bronze Age tumuli to be dug up for treasure, not for their cultural value but to boost the royal coffers. Similarly, the European desire for untold riches represented the driving force behind much of the American conquest, with devastating consequences for the gold objects produced by several cultures, such as the Incas and the La Tolita-Tumaco (Bouchard and Guerra present the analytical study of a gold figure from the latter civilisation).

7 If hoarding is the starting point of collecting, more enlightened approaches to antiquities in the Renaissance and in the age of Enlightenment led to the formation of important collections, many of which are now in public ownership and freely accessible for all to enjoy (some including some non-genuine objects, as illustrated by La Niece for The British Museum collections). However, the urge to own gold, archaeological gold in particular, is undiminished, and many private collectors compete for a very limited pool of genuine and legitimately available objects. There are many reasons for this: ranging from the psychological, almost primordial desire for gold; to the rise of an affluent middle class and nouveaux riches in many countries with their need to showcase their wealth and 'cultured' manners; and genuine interest in aesthetic beauty, art history and cultural heritage. Taken together, they result in a market demand that by far outstrips supply. The consequences are many: prices rise, even in times of global economic crisis; tomb robbery, illicit excavation and museum theft feed the market at the cost of wholesale destruction of our common cultural heritage; and forgers produce tirelessly new objects to satisfy the ballooning demand with copies, reproductions, imitations, and heavy restorations re-interpreting an object, by producing pastiches and more or less fantastic fraudulent inventions (Rastrelli et al.). One might argue that forging archaeological objects is a lesser evil, as compared to the looting of entire sites. However, the unchecked demand leads to an entire industry producing forgeries, thus causing cultural damage, by diluting, debasing and distorting the genuine archaeological record, the artistic and technological achievements, the aesthetic, religious and personal expressions of countless past people. 
8 The absence of discussions on illicit traffic and trade in forgeries from most conferences in the field of archaeological sciences led us to dedicate an entire day of AURUM to a special session entitled Forgeries, Trade and Authentication. After three invited talks by Pieter Meyers (Los Angeles County Museum of Art Conservation Center), Susan La Niece (Department of Conservation and Scientific Research, The British Museum) and Colonel Alberto Deregibus (Head of Command Office Carabinieri, Department for the Protection of Cultural Heritage, Rome), a roundtable discussion was dedicated to these questions (see Fig. 2). We won't be able to stop these illegal activities from happening; but it is important to highlight their corrosive effect on so many different aspects of society. We mentioned the destruction and debasement of our common cultural heritage already, but there are also other major issues for current societies; from loss of tax receipts for governments to the countless individual acts of fraud committed in the process, to the damage done to the potential for the development of an archaeological site for sustainable tourism and education, robbing the local population of their long-term livelihood.

This volume of Archeosciences is devoted to the scholarly study of archaeological gold objects, not from the art historical or aesthetic point of view typical of traditional collections and catalogues, but with the aim of unravelling the technical skills of the craftspeople who made these objects. Characterising their tools and materials as a way to understand their actions, their gestures allow us to place them within their unique geological, economic and cultural contexts and traditions (Perea illustrates in her paper the big advances reached by coupling different fields of research in the study of gold work, and gives an example in the paper by Perea and Hunt). Studying the tangible finds thus reveals the intangible wealth of the cultural heritage of craftspeople and artisans. This, in turn, will inform the study of those objects which have no proven pedigree, no documented historical or archaeological origin and whose authenticity is therefore in many cases open to dispute. Exploring authenticity combines art history and connoisseurship, an array of methods of scientific examination under many lights and radiations. It involves scientific analysis with portable instruments, as for example in the study of the Artemision objects by Melcher et al., and fixed equipment based on X-rays, mass spectrometry, synchrotrons (as developed by Radtke et al.), particle accelerators (as illustrated by Bobin and Guégan and by Demortier), and so on, and can be combined with detailed visual and microscopic examination techniques (examples of studies combining techniques are provided by Ferro et al. and Guerra et al.). In all cases, the skill of the detective is needed in the search for the wrong aesthetic, technical and material elements, which should not be there: it is never routine.

Following a rigorous selection and peer review process, we have arranged the accepted contributions in five overarching sections. The first, containing eleven papers, serves as an introduction and offers examples of the material and methodological foundations relevant for the study of archaeological gold. This covers the archaeological record of early gold objects as much as the geology of gold, and ancient gold mining. Examples here include the papers by Bergonzi and by Bennett on the occurrence of gold artefacts in Italian and South-East Asian archaeology; by Spiridonov \& Yanakieva on the mineralogy of gold, by Hauptmann et al. on early gold mining in Georgia, and by Tamas et al. on the geology of the gold exploited in Romania under Roman control. Other fundamental papers concern modern analytical approaches to characterise, 
provenance, and even date gold; papers by Eugster et al., Radtke et al. and Demortier are amongst those addressing these issues.

11 The second section contains the main 'meat' of the conference; twenty-one papers present individual case studies concerning the material characterisation and manufacturing skills of the ancient artisans, from Late Bronze Age Egypt right through to the $19^{\text {th }}$ century AD. The flow of these papers follows broadly chronological and cultural trends, from the origins in the Near East to the classical Mediterranean cultures and on to the early medieval and later European centres of developments in metal crafts. An important and impressive observation that emerges from reading these papers is the continuing manifestation of manufacturing skills at the highest levels, seemingly uninterrupted by the broad political and economic convulsions that tormented the Old World during those four thousand years. Individual cultures ebbed and flowed, flourished and perished; but overall humankind persevered, developing and refining its technical achievements in one way or another. Remarkable also within this broad advance is the exceptional, and often unique and unsurpassed, achievement of individual artists, stimulated by their own imagination, driven by their devotion, and maintained by their communities, religious orders, or wealthy patrons.

The previous section has shown how coherent and at the same time divers cultural and technological developments were across time and space in the old World. The New World, in contrast, approached gold in its own and independent manner; the paper by Ruvalcaba Sil et al. illustrates this by providing an overview of the artisans' gold work of Mesoamerica. This third section combines eight papers on gold work from this microcosmos of its own, with its unique gold deposits which are often geochemically quite distinct from gold sources in the old World, but also blessed with a plethora of unique archaeological styles, and burdened by unique archaeological problems of looting, forging and wholesale plunder, intricately linked to the political and economic realities of the last five hundred years. This section thus covers the entire sequence of gold work and its investigation, from studies of gold deposits to analytical methods and the investigation of iconic objects, and finally to the origin and use of gold for coinage and Christian decorations following the European dominance.

13 To some extent, all papers up to this point can be seen as a prelude to the fourth section, on authentication. Here, the accumulated expert knowledge is applied to address specific case studies, giving examples of the more fundamental concerns and showcasing the results of established and new methods. Of course, these papers only represent the tip of an iceberg, and here is not the place to repeat the discussion from the round table, and the many reasons why this is the case. Suffice it to say that if anything emerges from these papers, it is the recognition that there is no 'golden bullet' that delivers the final answer to all our problems; in some cases it is a specific chemical tracer (Bobin \& Guégan), in others a particular tool mark or wear mark (Formigli and Vella et al.), and in any case the scientific and technological investigation (Kuleff et al.) has to be fully integrated into an art historical and cultural study. 
Figure 1: The participants of Workshop AURUM: authentication and analysis of goldwork at the C2RMF laboratories

Figure 1 : Les participants du Workshop AURUM : authentification et analyse d'objets en or dans les laboratoires du C2RMF.

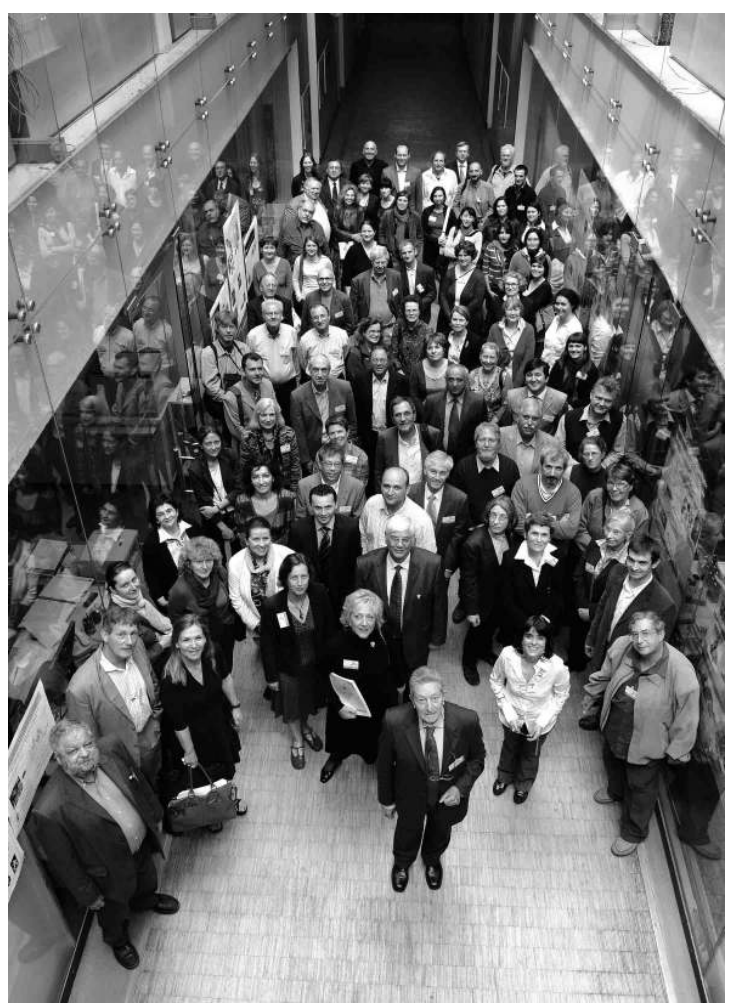

(photographie par Elsa Lambert, C2RMF)

(photograph by Elsa Lambert, C2RMF).

14 The fifth section finally combines papers on the restoration and conservation of gold artefacts, sometimes in known public collections (such as in the Portuguese National Archaeological Museum, Tissot et al.), sometimes discovered in particular environments, such as underwater excavations (in this volume, Berger describes those held in Alexandria and Aboukir Bay, Egypt). Given the inherent durability of gold itself, it is not surprising that the majority of these papers concern gold in its most delicate state: as leaf and foil covering other materials, such as wood, paint or gesso (see Mounier et al., Buccolieri et al. and Cavallo \& Verda). Some of these papers raise further interesting questions about the concept of authenticity and conservation of 'living objects'. It may be easy to decide how to best preserve a museum piece, kept under controlled conditions and frozen in time in the condition in which it was last found. But what about churches and their centrepieces, the altars (discussed by Le Gac et al. and Bidarra et al.)? These have important functions to fulfil for their current communities and need to be fit for purpose, but they are also pieces of art and part of our heritage and need to be preserved in the way they were first made to look like. Which authenticity does one preserve here: the authenticity of the original maker of the altar, or the authenticity of the current congregation using it, adapting it to their needs and changing artistic tastes and preferences?

There are important and divers questions to be asked in the study of archaeological gold objects. Should we simply adore and cherish their absolute beauty removed from any distraction, or should we see them embedded in a past culture, as expressions of 
beliefs and priorities? Should we see primarily their social significance, read their materiality as mere projections of something bigger, intangible, or should we deconstruct them, if not literally then metaphorically, to understand them as products of mundane acts of crafts and industry? Whose authenticity do we prioritise? The artist's, who made the object? The patron's, who facilitated its production? The current owner's, who holds it dear? What does the present state of the object tell us about its live history as an artefact, not just its creation but its use and repair, its adaptation and modification over time, and what does its present condition and whereabouts tell us about the changing fortunes and functions of the object? This collection of papers can not give answers, but it can still tell us a lot. Factual information, of course. Case studies inspiring one's own work, enabling comparisons to be drawn. The sheer range and diversity of approaches, the depth of individual scholarly knowledge that underpins these papers is impressive and heartening to see. On the other hand, it tells us also where the gaps are, where we still know far too little, and where we may have lost our heritage already. It is the nature of Archaeology that only a minute amount of material survives the ravages of time, even in the best of circumstances. Gold is no exception, and we may ever only see a tiny fraction of the true wealth and richness of our cultural heritage. What gold benefits from its durability once buried in the ground it suffers from its propensity for recycling before it gets there. Thus, it is our responsibility towards the peoples who made these objects, as well as towards our children and grand children, to preserve what we have, to enhance our understanding of what there is, to safeguard it against the greed of the individual and the ignorance of the uninformed. Analysing these objects scientifically and technologically reveals entirely new dimensions of knowledge about the artefacts themselves, their creators and the cultures from which they emanate; it is a profoundly constructive analysis, even if minute changes are made to the objects in the process.

\section{Acknowledgements}

16 We are very grateful for the many participants of the workshop AURUM who have together made it such a success, and who have submitted their manuscripts in time to be included in this volume. The support of many colleagues who acted as peer reviewers is much appreciated, as is the cooperation of the editors of ArcheoSciences in facilitating this volume. We are most grateful to Raul Carstocea for his excellent work in editing all the final manuscripts, ensuring where necessary the proper use of English, and who checked many references, and to Antoine Mattei who provided all the website development and support for the Workshop and the peer review process of this volume.

17 The European Commission, DG Research under FP6 contract 044480 (AUTHENTICO), the Research and Restoration Centre of the French Museums (C2RMF), the Direction of the French Museums of the Ministry of Culture and Communication (DMF-MCC), the French National Centre for Scientific Research (CNRS) - Institute of Chemistry, GdR3174-ChimArc, UMR171-LC2RMF, UMR6115-LPC2E and Paris A Delegation -, the Institute for Archaeo-Metallurgical Studies of the University College London, and Bruker AXS Microanalysis $\mathrm{GmbH}$, are gratefully acknowledged for funding and website hosting. 
Figure 2: Workshop AURUM roundtable on Forgeries, Trade and Authentication. Figure 2 : Table ronde du Workshop AURUM intitulé Faux, Commerce et Authentification.

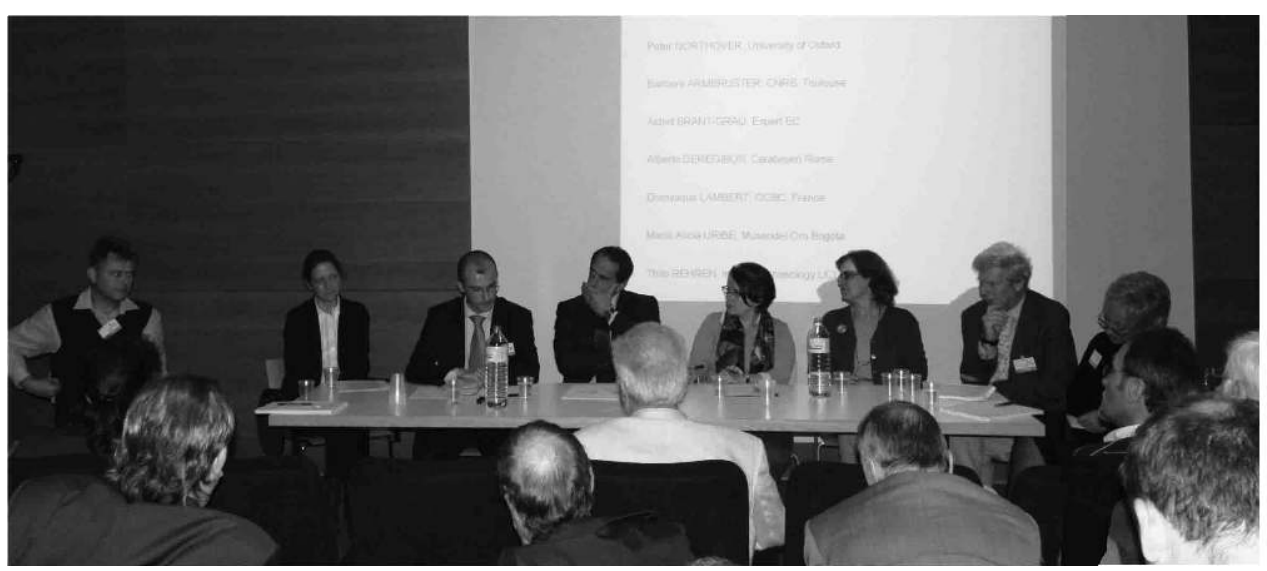

From left to right: Thilo Rehren (UCL - Institute of Archaeology), Maria Alicia Uribe (Gold Museum of the Banco de la República in Bogotá), Captain Dominique Lambert (Central Office for the Fight against Traffic in Cultural Goods of the French Criminal Investigation Department), Colonel Alberto Deregibus (Command Office Carabinieri, Department for the Protection of Cultural Heritage, Rome), Astrid Brandt-Grau (EU-DG Research-I3, Environmental Technologies and Pollution Prevention, Protection, Conservation and Enhancement of Cultural Heritage), Barbara Armbruster (CNRS, Université de Toulouse - Le Mirail), Peter Northover (Department of Materials, Oxford University), Maria Luisa Vitobello (Coordinator of AUTHENTICO)

De gauche à droite : Thilo Rehren (UCL-Institut d'Archéologie), Maria Alicia Uribe (musée de l'Or du Banco de la República à Bogotá), Capitaine Dominique Lambert (Office Central de lutte contre le trafic des Biens Culturels, France), Colonel Alberto Deregibus (Office Carabinieri, Département de Protection du Patrimoine Culturel, Rome), Astrid Brandt-Grau (EU-DG Recherche-I3, Environnement Technologies et Prévention de Pollution, Protection, Conservation et Amélioration du Patrimoine Culturel), Barbara Armbruster (CNRS, Université de Toulouse- Le Mirail), Peter Northover (Département de Matériaux, Université d'Oxford), Maria Luisa Vitobello (Coordinateur d'AUTHENTICO).

\section{ABSTRACTS}

In this introduction to volume 33 of Archeosciences, we provide a brief overview of the use and abuse of gold over time, and its different aspects, from the mine to the objects, their use, analysis, and restoration. For this purpose, we focus on the papers presented in this volume, which originate from the Workshop AURUM: authentication and analysis of goldwork, organised under the auspices of the EU-DG Research funded project AUTHENTICO. The main aim of this project was to develop tools and expertise for law enforcement agencies to combat illicit trade in antiquities and to fight fraud and forgeries; to do so requires an understanding of the diversity of the cultural, technical and material manifestations of gold artefacts, and their very specific combinations and expressions. Some of the scholarly foundations of this endeavour are illustrated by the selection of the 55 papers, arranged in five topical sections, which are introduced in this text.

Dans cette introduction au volume 33 d'ArcheoSciences, nous faisons un bref bilan du us et abus de l'or au long du temps, des divers aspects qu'il peut prendre de la mine à l'objet, et de l'utilisation des objets d'or, de leur analyse et de leur restauration. Ce bilan repose sur les articles présentés dans ce volume, qui émanent du Workshop AURUM : authentification et analyse d'objets en or, 
organisé sous les auspices du projet AUTHENTICO, financé par le DG-Recherche de la Commission Européenne. Le but principal de ce projet a été le développement d'outils et de compétences pour combattre le trafic illicite d'antiquités et pour lutter contre la fraude et le commerce de faux. Pour atteindre cette fin, il est nécessaire de comprendre la diversité des manifestations culturelles, techniques et matérielles des objets en or et leurs combinaisons et expressions très spécifiques. Quelques uns de ces fondements sont illustrés par les 55 articles, organisés en cinq sections thématiques, qui sont introduits par ce texte.

\section{INDEX}

Mots-clés: analyse, AURUM, faux, introduction, or

Keywords: analysis, AURUM, gold, introduction, forgery

\section{AUTHORS}

\section{MARIA FILOMENA GUERRA}

Laboratoire du Centre de Recherche et de Restauration des Musées de France, UMR171 CNRS, 14, quai François-Mitterrand, 75001 Paris, France. (maria.guerra@culture.gouv.fr)

\section{THILO REHREN}

UCL Institute of Archaeology, 31-34 Gordon Square, London WC1H OPY, United Kingdom. (th.rehren@ucl.ac.uk) 